\title{
MARKET IDENTIFICATION, OPPORTUNITIES, AND PROFITABILITY FOR THE SELECTED SEASONAL FRUITS IN THE CHITTAGONG HILL TRACTS AREA OF BANGLADESH
}

\author{
Md Jahurul Islam ${ }^{1+}$ \\ M Kamruzzaman ${ }^{2}$ \\ Md. Jamal Uddin ${ }^{3}$ \\ ${ }^{\prime}$ Khulna Agricultural University, Department of Agricultural Economics, \\ Khulna, Bangladesh. \\ Email:jahurul.bsmrau@gmail.com Tel: +88-01715299022 \\ ${ }^{\circ B}$ Bangabandhu Sheikh Mujibur Rahman Agricultural University, \\ Department of Agricultural Economics, Salna, Gazipur, Bangladesh. \\ Email:kzamanau@yahoo.com Tel: +88-02-9205339 \\ ${ }^{3}$ Regional Agricultural Research Station, BARI, Hathazari, Chattagram, \\ Bangladesh. \\ Email:jamaluddin1971@yahoo.com Tel: +8801815425857
}

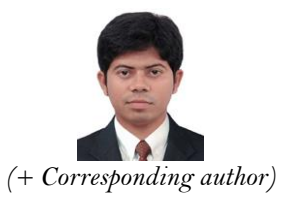

ABSTRACT

Article History

Received: 28 October 2021 Revised: 30 November 2021 Accepted: 15 December 2021 Published: 17 January 2022

Keywords

Chittagong hill tracts Seasonal fruits

Marketing channel

Market opportunities

Marketing profitability

Marketing efficiency.

\begin{abstract}
The study attempts to analyze suitable markets, market opportunities, and the estimation of the profitability of the selected seasonal fruits for the market intermediaries in Chittagong hill tracts of Bangladesh. The study was conducted at the CHT region such as; Bandarban and Rangamati district and some parts of the Chattagram region to document the socio-economic profile of the market actors of selected fruits and identify the suitable market opportunities and profitability of those fruits in the market. The chosen samples included 86 market actors. In the study area combined, $90 \%$ of Aratdar took formal education among all the market actors. In the case of education, $35 \%$ of market actors were found who have the level of education from primary to SSC, and $30 \%$ had primary education, $29 \%$ intermediaries were found to have finished their SSC level. The frequent and common variety sent to various markets was the Rangui variety of mango as the productions of other types were not more to supply. It was also observed that other fruits like jackfruit and litchi were sold more in the local market than supplying it to the distant market. When estimating growers' share, the study found the dominant channel for mango, jackfruit, and litchi to be the same (farmer- Faria-consumer), $64 \%, 38 \%$, and $57 \%$, respectively. The efficient marketing channel for mango (2.17) was (farmer-Bepari-Aratdar-retailer-consumer). For jackfruit, (farmer-Bepari-Aratdar-consumer) was found to have an efficient channel (1.27), and for litchi, (farmer-Faria-consumer) had the highest marketing efficiency (2.00).
\end{abstract}

Contribution/Originality: There is a dearth of studies regarding the marketing system and efficiency of seasonal fruits in the hilly areas of Bangladesh. This study is one of the few studies which identified the marketing channel, opportunities and profitability of the seasonal fruits for the market actors in the hilly areas of the Chattagram region of Bangladesh.

\section{INTRODUCTION}

The Chittagong Hill Tract, in southeastern Bangladesh, is the only sizeable hilly region in the country. They encompass an area of 13,184 square kilometers, with $92 \%$ highland, $2 \%$ medium highland, $1 \%$ medium lowland, and $5 \%$ residential areas and bodies of water. The CHT has roughly 1.35 million people, with about $51 \%$ indigenous people living in the frequently isolated upland areas [1]. 
For the past decade, mango, jackfruit, litchi, papaya, and watermelon have been the fruits of choice for massscale production in Bandarban, Rangamati, and Khagrachhari. The area has turned into a seasonal fruit hub with vast potentiality for expanding a food-processing sector. However, there is still a reliance on a centuries-old practice of intermediaries in the fruit trade [2]. These dealers go out to the cultivators a few weeks before harvest to negotiate prices for all products. They transport the produce to cities, where it is sold to smaller vendors. This strategy restricts the options available to farmers. At the same time, urbanites continue to charge exorbitant rates, implying that a significant portion of the fruits' value is pocketed somewhere along the road [2].

Fruit growers make a sizeable contribution to fruits production. Low volumes (minimal marketable surplus), poor quality, inconsistent supplies, and other factors limit their access to formalized markets. Simultaneously, local markets for the products are limited, forcing them to sell their products in far-flung urban and export markets, adding to their expensive transportation and marketing costs. Intermediaries such as assemblers, wholesalers, subwholesalers, commission agents, and retailers control existing supply chains. Producers can get as little as one-third to one-half of the final price in some instances, reflecting substantial marketing costs and margins [3]. Institutions such as cooperatives and commodity associations reduce marketing and transaction costs and risks by providing "markets" to the producers at their doorsteps. Transforming smallholder self-sustaining (non-market-oriented) agriculture into dynamic market-oriented sectors can create multiplier effects towards other sectors. This transition can enhance the non-farm sector by creating jobs and boosting income. Backward and forward production linkages and linkages emerging from improved revenues in the agricultural and non-farm sectors are examples of linkages. Presently, the rising demand for these seasonal commodities is allowing producers, particularly smallholder farmers, to diversify into commodities with a significant possibility of increased returns on land, labor, and capital.

Nevertheless, due to a lack of access to inputs and outputs, capital, technology, extension services, skills, natural resources (land, water), and other factors, there is concern regarding smallholder producers' ability to participate in market-oriented production [3]. So, identifying the suitable markets, market opportunities, and the estimation of the profitability of the selected seasonal fruits will reveal the market advantages for the market actors eventually. In light of the factors mentioned earlier, the current study was conducted for the three significant seasonal fruits (mango, jackfruits, and litchi) with the following purposes in mind.

i. To document the socioeconomic profile of the market actors in the study area.

ii. To identify the suitable market, marketing opportunities, and profitability for those fruits in the market.

\section{REVIEW OF THE LITERATURE}

As many researchers analyzed the marketing chain of fruits, identification of marketing channel, and the crucial problems affecting the market intermediaries, this study, in particular, addressed the marketing channel for the marketing intermediaries, marketing opportunities, and profitability across different chains in the study areas.

Some studies dealt with the marketing performances, marketing margin of fruits, growth in output, and trend analysis of major fruits in the CHT region [4-6]. Other studies found the production and growth rate of fruits, marketable and marketed surplus of fruits, socio-economic status of mango producers, etc. [7-9].

Tadesse, in his study, evaluated the marketing system for fruits, identification of marketing channels, quantification of marketing cost, and margin for fruits. He also suggested an apposite policy to develop the fruits marketing system in Ethiopia [4]. Marketing performance assessment for fruits plays a significant part in an ongoing or future fruit development plan to promote growth, economic development, food security, and poverty alleviation [4]. Market actors play a crucial role in ensuring a smooth marketing system, and their role is undoubtedly significant in the market development of any commodity. Dewan [7] in her study, found four types of intermediaries involved in the fruit marketing system. Her study revealed that the production growth rate for mango was highest in the study area, whereas banana records the negative growth rate in the hilly area [7]. Farmers with limited resources invest less in farming inputs such as insecticides and fertilizers, resulting in poorer 
yields and inferior quality goods Aujla, et al. [5]. Aujla, et al. [5] found that due to a lack of storage and transportation facilities, $25-40 \%$ of post-harvest losses occurred, reducing supply and putting increased pressure on pricing. Uddin, et al. [6] performed research on the output growth and trend analysis of significant fruits in the hilly areas of the Chattagram region. The study found out the factors which contributed to output growth, and it revealed that the area for all the fruits increased, and the highest increase was for guava and the lowest increase in area for jackfruit. The study recommends that to augment the growth rate of fruits, enhanced variety and management practices should be spread through special programs and reinforcing research and extension links in this region [6]. A lack of transportation, exploitation by intermediaries, and market information impeded the feasibility and profitability of AIVs businesses [10]. Producer groups were linked to formal and informal marketplaces through marketing models relevant to all actors in the value chain to overcome these flaws [10]. According to a cost-benefit analysis of mango production, ten mango cultivars are lucrative with amplified working capital and human labor development. Mango farming has a higher cost of harvesting, sorting, and grading than other crops. Although respondents agreed that the Rajshahi district is profitable in mango production, more research into different variables and characteristics is needed [9]. After reviewing all of the above studies, it can be noted that there is a shortage of adequate research in the Chittagong Hill Tracts on the marketing system of seasonal fruits. This study will address the research gap by identifying the marketing channel and profitability of the seasonal fruits for the market actors in the hilly areas of the Chattagram region of Bangladesh.

\section{METHODOLOGY}

\subsection{Study Site Selection}

Since choosing the study area is a crucial step, it largely depends upon the study's objectives. Based on the high concentration of fruits production and cultivation, the hilly areas, i.e., Bandarban and Rangamati districts, were chosen to fulfill the study purpose.

\subsection{Sampling Techniques}

Market intermediaries such as; Faria, Bepari, Aratdar, wholesalers, and retailers make up the population of this study. To accomplish the aim of the study, the researcher used stratified random sampling to obtain data from market actors. 86 intermediaries or market actors were selected randomly from Bandarban and Rangamati districts and the different parts of the Chittagong and Feni region of the country Table 1.

Table 1. Sample distribution of market actor.

\begin{tabular}{|c|c|c|c|c|c|c|c|c|c|c|c|c|}
\hline \multirow{2}{*}{ 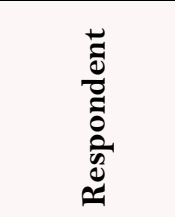 } & \multicolumn{3}{|c|}{ Bandarban } & \multicolumn{3}{|c|}{ Rangamati } & \multicolumn{3}{|c|}{ Chittagong \& Feni zone } & \multicolumn{3}{|c|}{ Total } \\
\hline & $\begin{array}{l}0 \\
\dot{\infty} \\
\tilde{\Xi} \\
\dot{\Sigma}\end{array}$ & 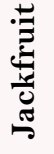 & 苞 & \begin{tabular}{l}
0 \\
$\dot{\infty}$ \\
\multirow{\Xi}{*}{}
\end{tabular} & 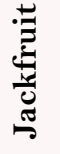 & 苞 & \begin{tabular}{l}
0 \\
$\dot{\infty}$ \\
\multirow{\Xi}{\Sigma}{}
\end{tabular} & 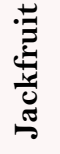 & 苞 & $\begin{array}{l}0 \\
\infty \\
\text { స్ } \\
\sum\end{array}$ & 苞苞 & 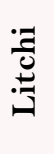 \\
\hline Faria & 4 & 1 & 1 & 3 & 2 & 1 & $\mathrm{O}$ & $\mathrm{O}$ & $\mathrm{O}$ & 7 & 3 & 2 \\
\hline Wholesaler & 3 & 1 & 1 & 4 & 1 & 4 & 1 & $\mathrm{O}$ & 1 & 8 & 2 & 6 \\
\hline Retailer & 6 & 1 & 2 & 5 & 2 & 4 & 1 & $\mathrm{O}$ & 1 & 12 & 3 & 7 \\
\hline Bepari & 8 & 2 & 2 & 4 & 4 & 1 & $\mathrm{O}$ & $\mathrm{O}$ & $\mathrm{O}$ & 12 & 6 & 3 \\
\hline Aratdar & $\mathrm{O}$ & $\mathrm{O}$ & $\mathrm{O}$ & $\mathrm{O}$ & $\mathrm{O}$ & $\mathrm{O}$ & 5 & 7 & 3 & 5 & 7 & 3 \\
\hline All & 21 & 5 & 6 & 16 & 9 & 10 & 7 & 7 & 5 & 44 & 21 & 21 \\
\hline
\end{tabular}

\subsection{Collection of Data}

The primary data were collected through personal interviews with the respondents using an interview schedule in the study. The researcher himself collected data from the market intermediaries such as; Faria, Bepari, Aratdar, wholesalers, and retailers. Primary data were collected from the hilly areas of the Chattagram region such as; Bandarban, and Rangamati districts and some parts of Chattagram city from May 2016 to August 2016. 


\subsubsection{Data Collection from Intermediaries}

The intermediaries refer to those people who act between the fruits growers and consumers. The important intermediaries are 'Faria,' 'Bepari,' 'Aratdar,' 'Wholesaler,' and retailer. Information was collected on trade volume, marketing costs (depreciation on investment capital, interest on running capital, transport cost, commission, market toll, wastage, etc.), mode of sales, purchase and sale prices, price formation, gross and net margins, and marketing constraints, etc. For Bepari, Faria, Wholesaler, and retailers, similar methods were followed. Among these intermediaries, Bepari, and Wholesaler, they transport fruits to other districts in the country.

\subsection{Data Analysis and Analytical Techniques}

Data obtained from questionnaires and interviews were coded where appropriate, entered into a Microsoft EXCEL database system and analyzed using SPSS Statistical Software. Average and percentage ratios were estimated using the EXCEL sheet. Descriptive statistics were used to describe the variables.

\subsubsection{Marketing Opportunities and Profitability for Market Actor}

3.4.1.1. Marketing Cost of Market Actor

The marketing costs mainly include costs for various market operations like transportation, loading and unloading, market toll, rents, staff salary, electricity, generator cost, commission, wastage, depreciation, and other miscellaneous expenses. The items of the marketing costs vary with the type of intermediaries.

The Total marketing cost incurred by the farmers and intermediaries in a channel is estimated by the following formula:

$\mathrm{C}=\mathrm{C}_{\mathrm{f}}+\mathrm{C}_{\mathrm{m} 1}+\mathrm{C}_{\mathrm{m} 2}+\mathrm{C}_{\mathrm{m} 3}+\ldots \ldots \ldots \ldots \ldots \ldots+\mathrm{C}_{\mathrm{mi}}$

$\mathrm{C}=$ Total cost of fruits marketing in a channel.

$\mathrm{C}_{\mathrm{f}}=$ Cost paid by the producer when commodity moves.

$\mathrm{C}_{\mathrm{mi}}=$ Cost incurred by the $\mathrm{i}^{\text {th }}$ middlemen in buying and selling fruits in a channel. $(\mathrm{I}=1,2,3$

\subsubsection{Marketing Margin of Market Actor}

The following formula estimated the marketing margin:

Marketing Margin $(\mathbf{T k} / \mathbf{k g})=$ Sales price $(\mathrm{Tk} / \mathrm{Kg})-$ Purchase price $(\mathrm{Tk} / \mathrm{Kg})$

The following formula calculated the net marketing margins of the intermediaries (after physical losses):

Net marketing margin (Value Addition $)=$ Sales price $-($ Purchase price + Marketing cost $)$

\subsubsection{Marketing Performance}

Marketing performance is evaluated using different measures of marketing efficiency as described by Shepherd [11]; Hugar and Hiremath [12] and Acharya and Agarwal [13]. The present study will investigate marketing efficiency by examining price spread, growers' share, and Acharya's methods for estimating efficiency. The methods for studying these estimates are given in the following.

\section{Price spread}

Price spread $=$ Price paid by consumers - Price received by the growers

Grower's share

\section{Growers' share (percent) $=\frac{\text { Price received by the fruit growers }}{\text { Customers' price }} \times 100$}

Acharya's method for estimating marketing efficiency.

In this method, the marketing efficiency will measure using the following formula: 


\section{Marketing efficiency $=\frac{F P}{(\mathrm{MC}+\mathrm{MM})}$}

Where,

$$
\begin{aligned}
& \mathrm{FP}=\text { Prices received by the farmer. } \\
& \mathrm{MC}=\text { Total marketing cost. } \\
& \mathrm{MM}=\text { Net marketing margin. }
\end{aligned}
$$

\section{RESULTS AND DISCUSSION}

\subsection{Socio-Economic Characteristics of Market Intermediaries}

The analysis on this demographic characteristic highlighted that the average age of types of intermediaries was 37 years to 42 years. Age is a crucial factor in skill development and enhancing marketing decisions. Literate people can have better access to the relevant information regarding food and livelihood security. It is observed from the study that among the market actors, $72 \%$ of Faria had formal education while $28 \%$ were illiterate. Among wholesalers, $85 \%$ had formal education, and 15\% were illiterate. Among retailers, $83 \%$ had formal education, and their education ratio was more between primary to SSC. In the case of Bepari, $80 \%$ had formal education, and they also had the same higher ratio of education level between primary to SSC like the retailer. The highest education ratio was observed for Aratdar, and the study revealed that 90\% of Aratdar took formal education, and only $10 \%$ were illiterate (Table 2). In all categories of market intermediaries, Bengali and Chakma were the distinct groups. Bengali were more in number in all groups than any other ethnic group. The only exceptions were in the group of Bepari, where Bengali, Chakma, and Bawm communities had involved themselves in trade.

Table 2. Socio-demographic characteristics of market intermediaries.

\begin{tabular}{l|c|c|c|c|c}
\hline \multirow{2}{*}{ Characteristics } & \multicolumn{5}{c}{ Market Intermediaries } \\
\cline { 2 - 6 } & Faria & Wholesaler & Retailer & Bepari & Aratdar \\
\hline Age (years) & 37 & 42 & 42 & 41 & 41 \\
\hline Ethnic Characteristics (\%) & 57 & 69 & 83 & 60 & 100 \\
\hline Bengali & 43 & 31 & 17 & 7 & 0 \\
\hline Chakma & 0 & 0 & 0 & 0 & 0 \\
\hline Marma & 0 & 0 & 0 & 33 & 0 \\
\hline Bawm & \multicolumn{5}{|l}{} \\
\hline Gender (in \%) & 100 & 100 & 100 & 100 & 100 \\
\hline Male & 0 & 0 & 0 & 0 & 0 \\
\hline Female & 0 & 15 & 22 & 20 & 0 \\
\hline Marital Status (\%) & 100 & 85 & 78 & 80 & 100 \\
\hline Single & 29 & 15 & 17 & 20 & 10 \\
\hline Married & 43 & 23 & 22 & 20 & 40 \\
\hline Level of education (\%) & 29 & 31 & 33 & 33 & 50 \\
\hline Illiterate & 0 & 31 & 28 & 27 & 0 \\
\hline Primary & 0 & 0 & 0 & 0 & 0 \\
\hline Primary to SSC & 0 & 0 & 0 & 0 & 0 \\
\hline SSC & 5 & 5 & 5 & 5 & 5 \\
\hline HSC
\end{tabular}

\subsection{Market Identification for Seasonal Fruits}

Several market places were identified in the study areas where seasonal fruits were rigorously sold. In the case of mango for Bandarban, the local markets where Faria and Bepari would bring and sell their product was Bandarban Sadar market, Balaghata Bazar. The Bepari would bring his product were in different parts of Chittagong city: Satkania, Keranihat, Dohazari, Cox's Bazar, BRTC market, etc. Figure 1. The frequent and 
common variety sent to various markets was the Rangui variety of mango as the productions of other types were not more to supply. It was also observed that other fruits like jackfruit and litchi were sold more in the local market than supplying it to the distant market. Farmer and the market actors could not profit, sending this to the other remote market as the marketing costs demand more for these fruits than increasing its production. In Rangamati, demand for mango variety like Amrapali was more as it produced more in number. But, this year, this variety meets up lesser need than the previous years as the productions were not higher to mention. So, the price was higher in the market for this variety.

There are other mango varieties that were sold in the local market, such as; Rangamati Banarupa Bazar, Ranirhat Bazar, Rauzan market, etc. This year the jackfruit and pineapple production were more in Rangamati than any other fruits. Market actors like Faria and Bepari were more in Ghagra Bazar for selling jackfruit and pineapple. Most of the fruit growers were found who would bring these fruits directly into the market to sell. The other suitable market for seasonal fruits (Specially Jackfruit and pineapple) from Rangamati was sent through Bepari in the market like Chittagong Amin market, Bohoddar hat Bazar, Firingi Bazar, BRTC market, etc. Some market actors (Specially Bepari), both from Bandarban and Rangamati, sold their fruits in the feni and Dhaka markets Figure 1. Though this number was not so high, they would send more in this distant market if the market actors got some incentives.

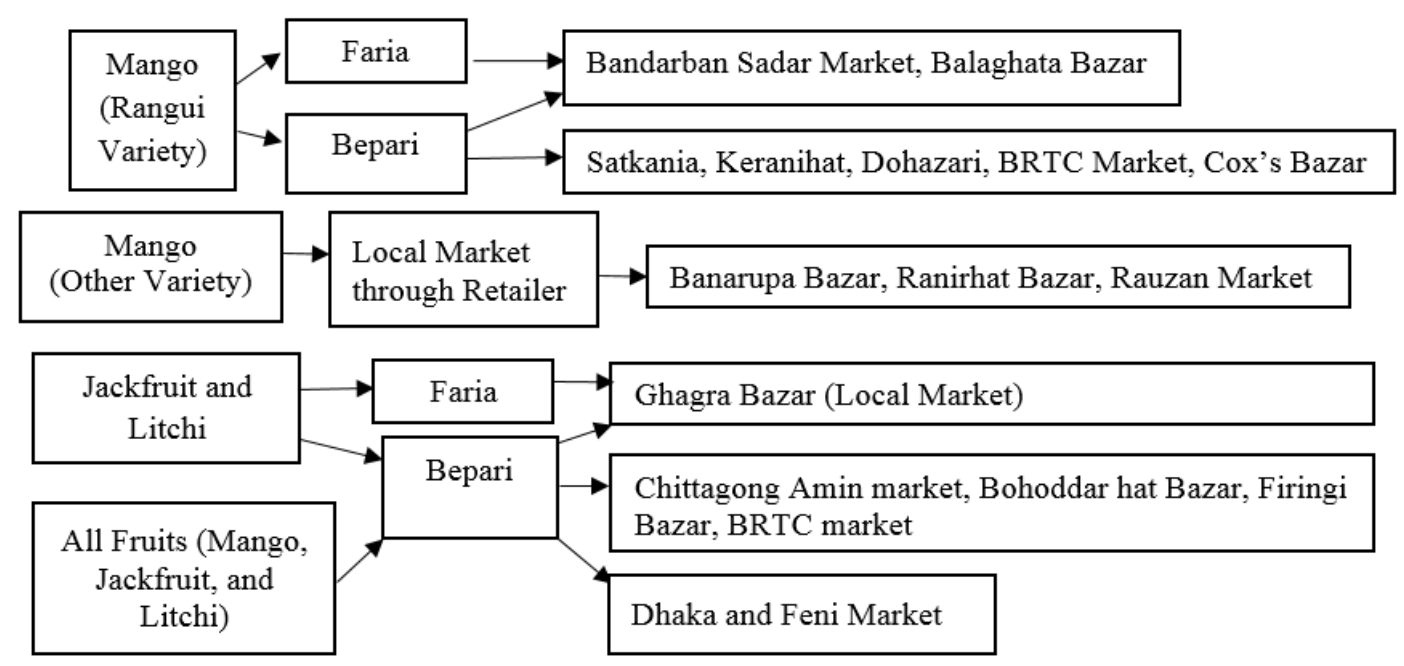

Figure 1. Identification of the market for the selected fruits by the market actors.

\subsection{Marketing Performance and Opportunities}

\subsubsection{Marketing Cost of Market Intermediaries}

Tables 3, 4, and 5 indicate different marketing costs related to the transaction of mango, jackfruit, and litchi by Faria, wholesaler, retailer, Bepari, and Aratdar. As in the study areas, most Farias sold their fruits to a distant place to get a better price. It was observed from Table 3 that, in the case of mango, among all the cost items, the market charge and fee were more significant than the other items. In the case of a wholesaler, retailer, and Aratdar, transportation cost was higher than the other items. In contrast, in the case of Bepari, depreciation cost was higher among all the items of marketing cost. In Table 4, except for wholesalers, the marketing cost of jackfruit was higher for Faria, retailer, Bepari, and Aratdar. Overall, the marketing cost of jackfruit was higher for Faria than the other market actors. In Table 5, it was observed that, in the case of litchi, the market fee and the toll were higher in amount for Faria and wholesaler than the other cost items. Also, the rent and maintenance fee was higher for retailers and Aratdar than the other items for litchi. From Table 5, it can be said that depreciation cost was higher than any other items for Bepari in the case of litchi marketing. Overall, it can be interpreted from Table 4 that the cost of litchi marketing was more significant for wholesalers than other market actors. 
Table 3. Total Cost of Mango marketing of different market actors (Tk. / ton).

\begin{tabular}{|c|c|c|c|c|c|c|}
\hline \multirow[t]{2}{*}{ SL. No. } & \multirow[t]{2}{*}{ Cost Items } & \multicolumn{5}{|c|}{ Market intermediaries } \\
\hline & & Faria & Wholesaler & Retailer & Bepari & Aratdar \\
\hline 1 & Transportation & 1692.86 & 4075 & 3275 & 925 & 2200 \\
\hline 2 & Packing & 78.57 & 300 & 244.167 & 178 & 20 \\
\hline 3 & Loading/Unloading & $\mathrm{O}$ & 494 & 620.84 & 292.42 & 202 \\
\hline 4 & Grading & $\mathrm{O}$ & 62.5 & 92 & 10 & 24 \\
\hline 5 & Labor & 9.28 & 441.25 & 560.84 & 597.25 & 130 \\
\hline 6 & Sweeper & $\mathrm{O}$ & 307.5 & 280 & 2.75 & $\mathrm{O}$ \\
\hline 7 & Guard & $\mathrm{O}$ & 62.5 & 41.67 & $\mathrm{O}$ & $\mathrm{O}$ \\
\hline 8 & Weight & 48.57 & $\mathrm{O}$ & $\mathrm{O}$ & 11 & $\mathrm{O}$ \\
\hline 9 & Depreciation & 657.15 & 2106.25 & 1612.50 & 1248.75 & 1960 \\
\hline 10 & Market Charge \& Fee & 2142.85 & 870.625 & 792.92 & 736.25 & 336 \\
\hline 11 & Rent & $\mathrm{O}$ & 1000 & 925 & 144 & 1550 \\
\hline 12 & Electricity & $\mathrm{O}$ & 435 & 398.34 & 38 & 480 \\
\hline 13 & Submit & 225 & 21.25 & 68.34 & $\mathrm{O}$ & $\mathrm{O}$ \\
\hline 14 & Generator & $\mathrm{O}$ & 71 & 105.67 & 5 & 50 \\
\hline 15 & Aratdar cost & $\mathrm{O}$ & 34.37 & 22.92 & 75 & $\mathrm{O}$ \\
\hline 16 & Personal & 203.57 & 211.37 & 220 & 115.34 & 140 \\
\hline 17 & Mobile & 171.43 & 12.875 & 131.25 & 80.92 & 100 \\
\hline \multirow[t]{2}{*}{18} & Others & $\mathrm{O}$ & $\mathrm{O}$ & $\mathrm{O}$ & $\mathrm{O}$ & $\mathrm{O}$ \\
\hline & Total & 5229.286 & 10614.25 & 9391.167 & 18601.2 & 7191 \\
\hline
\end{tabular}

Table 4. Total Cost of Jackfruit Marketing of different market intermediaries (Tk/'OO no.)

\begin{tabular}{|c|c|c|c|c|c|c|}
\hline \multirow[t]{2}{*}{ SL. No. } & \multirow[t]{2}{*}{ Cost Items } & \multicolumn{5}{|c|}{ Market intermediaries } \\
\hline & & Faria & Wholesaler & Retailer & Bepari & Aratdar \\
\hline 1 & Transportation & 350 & 450 & 633.33 & 783.33 & 842.857 \\
\hline 2 & Packing & $\mathrm{O}$ & $\mathrm{O}$ & $\mathrm{O}$ & $\mathrm{O}$ & $\mathrm{O}$ \\
\hline 3 & Loading/Unloading & $\mathrm{O}$ & 145 & 246.67 & 383.33 & 151.43 \\
\hline 4 & Grading & $\mathrm{O}$ & $\mathrm{O}$ & $\mathrm{O}$ & $\mathrm{O}$ & $\mathrm{O}$ \\
\hline 5 & Labour & 83.34 & 15 & 243.33 & 308.33 & 357.14 \\
\hline 6 & Sweeper & $\mathrm{O}$ & 150 & 100 & $\mathrm{O}$ & $\mathrm{O}$ \\
\hline 7 & Guard & $\mathrm{O}$ & $\mathrm{O}$ & $\mathrm{O}$ & 8.33 & $\mathrm{O}$ \\
\hline 8 & Weight & $\mathrm{O}$ & $\mathrm{O}$ & $\mathrm{O}$ & $\mathrm{O}$ & $\mathrm{O}$ \\
\hline 9 & Depreciation & 216.67 & 300 & 366.67 & 308.33 & 207.14 \\
\hline 10 & Market Tool & 283.34 & 550 & 483.33 & 386.17 & 168.57 \\
\hline 11 & Rent & $\mathrm{O}$ & 275 & 533.33 & 66.67 & 500 \\
\hline 12 & Electricity & $\mathrm{O}$ & 475 & 166.67 & $\mathrm{O}$ & 307.14 \\
\hline 13 & Submit & 150 & 25 & 16.67 & $\mathrm{O}$ & 0.72 \\
\hline 14 & Generator & $\mathrm{O}$ & 225 & 23.33 & $\mathrm{O}$ & 26.43 \\
\hline 15 & Aratdar cost & $\mathrm{O}$ & $\mathrm{O}$ & $\mathrm{O}$ & $\mathrm{O}$ & $\mathrm{O}$ \\
\hline 16 & Personal & 183.34 & 200 & 141.67 & 113.34 & 146.43 \\
\hline 17 & Mobile & 150 & 125 & 111.67 & 67.83 & 100 \\
\hline \multirow[t]{2}{*}{18} & Others & $\mathrm{O}$ & $\mathrm{O}$ & $\mathrm{O}$ & $\mathrm{O}$ & $\mathrm{O}$ \\
\hline & Total & 1416.67 & 2935 & 3066.66 & 2425.67 & 2643.571 \\
\hline
\end{tabular}

\subsubsection{Marketing Margin of Market Intermediaries}

In this study, the gross marketing margin of each trader was estimated by deducting the purchase price of fruits (mango, jackfruit, and litchi) from the sale price. In contrast, the net margin/profit component was estimated by deducting the marketing cost from the gross marketing margin. Table 6 represents the marketing margin of three mango varieties. The highest net margin for Amrapali variety was Tk. 24771 per ton, received by Faria, and their profits were higher than others. In the case of the Rangui variety, while the gross margin received by Bepari is higher than the other actors, the net margin or profit was more significant for the retailer (Tk. 10609 per ton) than the other actors. But in the case of the local variety of mango, the net margin was higher for Faria than the other market actors. It can be interpreted finally that, net margin of Bepari was smaller than the other market actors in all three varieties of mango. The same method was followed to estimate the marketing margin of jackfruit for market 
intermediaries as mango intermediaries. Here, the net marketing margin of Faria was higher than other intermediaries when they supplied jackfruit in the market (Table 7), and the amount of net margin or profit was Tk. 1883 per 100 pieces. Here, the standard sizeable jackfruit was considered for estimation purposes. The same thing happened on litchi intermediaries. There were few differences in marketing margin between litchi intermediaries. According to the result, the highest net margin was received by Bepari for litchi trading (Table 8). The actual situation in other cases may be different because intermediaries handle the additional volume of fruits, and after that actual difference in marketing margin will be caused to happen.

Table 5. Total Cost of litchi marketing of different market intermediaries (Tk. / OOO no.)

\begin{tabular}{|c|c|c|c|c|c|c|}
\hline \multirow{2}{*}{ SL. No. } & \multirow{2}{*}{ Cost Items } & \multicolumn{5}{|c|}{ Market intermediaries } \\
\hline & & Faria & Wholesaler & Retailer & Bepari & Aratdar \\
\hline 1 & Transportation & 175 & 200 & 46.43 & 183.34 & 216.67 \\
\hline 2 & Packing & 37.5 & 44.17 & 34.28 & 45 & 38.33 \\
\hline 3 & Loading/Unloading & $\mathrm{O}$ & 158.33 & 44.28 & $\mathrm{O}$ & 50 \\
\hline 4 & Grading & $\mathrm{O}$ & $\mathrm{O}$ & 6.43 & $\mathrm{O}$ & 23.34 \\
\hline 5 & Labor & $\mathrm{O}$ & 20.83 & $\mathrm{O}$ & 150 & 55 \\
\hline 6 & Sweeper & $\mathrm{O}$ & 15 & 21.43 & $\mathrm{O}$ & $\mathrm{O}$ \\
\hline 7 & Guard & $\mathrm{O}$ & $\mathrm{O}$ & 14.28 & $\mathrm{O}$ & $\mathrm{O}$ \\
\hline 8 & Weight & $\mathrm{O}$ & $\mathrm{O}$ & $\mathrm{O}$ & $\mathrm{O}$ & $\mathrm{O}$ \\
\hline 9 & Depreciation & 175 & 200 & 117.14 & 250 & 133.34 \\
\hline 10 & Market Toll and fee & 225 & 258.33 & 214.28 & 175 & 216.67 \\
\hline 11 & Rent and Maintenance & $\mathrm{O}$ & 300 & 250 & $\mathrm{O}$ & 416.67 \\
\hline 12 & Electricity & $\mathrm{O}$ & 191.67 & 235.72 & $\mathrm{O}$ & 96.67 \\
\hline 13 & Submit & 27.5 & 12.5 & 2.86 & 16.67 & $\mathrm{O}$ \\
\hline 14 & Generator & $\mathrm{O}$ & 44.17 & 42.14 & $\mathrm{O}$ & 75 \\
\hline 15 & Aratdar cost & $\mathrm{O}$ & $\mathrm{O}$ & $\mathrm{O}$ & $\mathrm{O}$ & $\mathrm{O}$ \\
\hline 16 & Personal & 112.5 & 133.14 & 121.43 & 91.67 & 150 \\
\hline 17 & Mobile & 110 & 97.5 & 102.86 & 108.34 & 116.67 \\
\hline \multirow[t]{2}{*}{18} & Others & $\mathrm{O}$ & $\mathrm{O}$ & $\mathrm{O}$ & $\mathrm{O}$ & $\mathrm{O}$ \\
\hline & Total & 862.5 & 1667.5 & 1253.57 & 1020 & 900.68 \\
\hline
\end{tabular}

Table 6. Marketing margin of different mango intermediaries (in BDT).

\begin{tabular}{|c|c|c|c|c|c|c|}
\hline \multicolumn{7}{|c|}{ For Amrapali variety } \\
\hline \multirow{2}{*}{ Sl. No. } & \multirow{2}{*}{ Particulars } & \multicolumn{5}{|c|}{ Market intermediaries } \\
\hline & & Faria & Wholesaler & Retailer & Bepari & Aratdar \\
\hline a. & Purchase price & 45000 & 55000 & 75000 & 40000 & 60000 \\
\hline $\mathrm{b}$. & Sale price & 75000 & 70000 & 90000 & 60000 & 75000 \\
\hline c. & Gross margin(b-a) & 30000 & 15000 & 15000 & 20000 & 15000 \\
\hline $\mathrm{d}$. & Marketing cost & 5229.286 & 10614.25 & 9391.167 & 18601.2 & 7191 \\
\hline e. & Net margin $(\mathrm{c}-\mathrm{d})$ & 24771 & 4386 & 5608.83 & 1399 & 7809 \\
\hline \multicolumn{7}{|c|}{ (For Rangui Variety) } \\
\hline a. & Purchase price & 25000 & 40000 & 40000 & 20000 & 40000 \\
\hline b. & Sale price & 40000 & 55000 & 60000 & 40000 & 50000 \\
\hline c. & Gross margin(b-a) & 15000 & 15000 & 20000 & 20000 & 10000 \\
\hline $\mathrm{d}$. & Marketing cost & 5229.286 & 10614.25 & 9391.167 & 18601.2 & 7191 \\
\hline e. & Net margin $(\mathrm{c}-\mathrm{d})$ & 9770.72 & 4385.75 & 10608.83 & 1398.8 & 2809 \\
\hline \multicolumn{7}{|c|}{ (For Local variety) } \\
\hline a. & Purchase price & 30000 & 45000 & 50000 & 30000 & $\mathrm{O}$ \\
\hline b. & Sale price & 50000 & 60000 & 70000 & 50000 & $\mathrm{O}$ \\
\hline c. & Gross margin(b-a) & 20000 & 15000 & 20000 & 20000 & $\mathrm{O}$ \\
\hline d. & Marketing cost & 5229.286 & 10614.25 & 9391.167 & 18601.2 & $\mathrm{O}$ \\
\hline e. & Net margin $(\mathrm{c}-\mathrm{d})$ & 14770.72 & 4385.75 & 10608.83 & 1398.8 & $\mathrm{O}$ \\
\hline
\end{tabular}


Table 7. Marketing margin of different jackfruit intermediaries (in BDT).

\begin{tabular}{c|c|c|c|c|c}
\hline $\begin{array}{c}\text { Market } \\
\text { intermediaries }\end{array}$ & $\begin{array}{c}\text { a. Purchase price } \\
\text { (100 piece) }\end{array}$ & $\begin{array}{c}\text { b. Sales price } \\
\text { (100 pieces) }\end{array}$ & $\begin{array}{c}\text { c. Gross } \\
\text { margin(b-a) }\end{array}$ & $\begin{array}{c}\text { d. Marketing } \\
\text { cost }\end{array}$ & $\begin{array}{c}\text { e.Net margin } \\
\text { (c-d) }\end{array}$ \\
\hline Faria & 2000 & 5300 & 3300 & 1416.67 & 1883.33 \\
\hline Wholesaler & 2800 & 6000 & 3200 & 3135 \\
\hline Retailer & 5300 & 10000 & 4700 & 3233.33 & 1466.67 \\
\hline Bepari & 2000 & 5000 & 3500 & 3280.67 & 219.33 \\
\hline Aratdar & 5000 & 7000 & 2000 & 1843.571 & 156.43 \\
\hline
\end{tabular}

Table 8. Marketing margin of different litchi intermediaries (in BDT)

\begin{tabular}{|c|c|c|c|c|c|c|}
\hline $\begin{array}{l}\text { Market } \\
\text { intermediaries }\end{array}$ & $\begin{array}{c}\text { Litchi } \\
\text { Variety }\end{array}$ & $\begin{array}{c}\text { a. Purchase } \\
\text { price (100 } \\
\text { piece) }\end{array}$ & $\begin{array}{c}\text { b. Sales } \\
\text { price (100 } \\
\text { pieces) }\end{array}$ & $\begin{array}{c}\text { c. Gross } \\
\text { margin(b-a) }\end{array}$ & $\begin{array}{c}\text { d. Marketing } \\
\text { cost }\end{array}$ & $\begin{array}{c}\text { e.Net margin } \\
(c-d)\end{array}$ \\
\hline \multirow{2}{*}{ Faria } & China 3 & 2000 & 3500 & 1000 & 862.5 & 138 \\
\hline & China 2 & 1500 & 2500 & 1000 & 862.5 & 138 \\
\hline \multirow{2}{*}{ Wholesaler } & China 3 & 2000 & 3800 & 1800 & 1667.5 & 133 \\
\hline & China 2 & 1200 & 3000 & 1800 & 1667.5 & 133 \\
\hline \multirow{2}{*}{ Retailer } & China 3 & 3500 & 5000 & 1500 & 1254 & 246 \\
\hline & China 2 & 2500 & 4000 & 1500 & 1254 & 246 \\
\hline \multirow{2}{*}{ Bepari } & China 3 & 1500 & 3000 & 1500 & 1020 & 480 \\
\hline & China 2 & 1200 & 2500 & 1300 & 1020 & 280 \\
\hline \multirow{2}{*}{ Aratdar } & China 3 & 3000 & 4000 & 1000 & 900.68 & 99.32 \\
\hline & China 2 & 2500 & 3500 & 1000 & 900.68 & 99.32 \\
\hline
\end{tabular}

\subsection{Marketing Efficiency}

Marketing efficiency is a measure of market performance. The movement of goods from producers to the ultimate consumers at the lowest possible cost consistent with the service desired by the consumers is termed efficient marketing [14]. Here, in case of estimating price spread, growers' share, and marketing efficiency, averages of prices of three mango varieties have been counted. For litchi, the China-3 type has been calculated for estimation purposes.

\subsubsection{Price Spread}

For measuring marketing efficiency, price spread is an important measure. According to the research result, the price spread was highest when mango was transferred by the channel [Farmer - Bepari - Aratdar (Chittagong market) - Retailer - Consumer], and the amount was TK. 32400. For comparing different channels, the price spread of all other possible channels was calculated and presented in Table 9. The price spread was highest for jackfruit marketing in the (Farmer - Faria - Retailer - Consumer) channel (Tk.8000 per 100 pieces). For litchi marketing, the highest price spread was seen in the [Farmer - Bepari - Aratdar (Chittagong) - Retailer (Chittagong) - Consumer] channel, which was Tk. 3500 per 1000 pieces.

\subsubsection{Grower's Share}

Grower's share is another important measure of marketing efficiency. Results showed that the grower's share was highest in the (Farmer - Faria - Consumer) channel during mango marketing (63.64 \%) (Table 10). During jackfruit supply, fruit growers also share highest in (Farmer - Faria- Consumer) channel which was $38 \%$. And the same case happened for the litchi growers. Litchi growers got the largest share in the (Farmer - Faria - Consumer) channel $(57 \%)$. So, for all the three fruits, the common channel where growers' share ranked high was (Farmer Faria - consumer channel) (Table 10). 


\subsubsection{Acharya's Method for Estimating Marketing Efficiency}

The performance of marketing was assessed based on Acharya's formula of marketing efficiency. Results (Table 11) showed that for mango marketing, the most efficient marketing channel was [Farmer - Bepari - Aratdar (Chittagong market) - Retailer - Consumer)] and that was 2.17. In the case of jackfruit marketing, the most efficient channel was [Farmer - Bepari - Aratdar (Chittagong market) - Consumer (Chittagong)], and it was 1.27 Table 11. For litchi marketing, the efficient channel was (Farmer - Faria - Consumer), and the marketing efficiency was 2.00 higher than the other channel.

Table 9. Price Spread in marketing channel of fruits (mango, jackfruit, and litchi).

\begin{tabular}{|c|c|c|c|}
\hline Marketing channel & $\begin{array}{l}\text { Price received } \\
\text { by fruit growers } \\
\text { (in } \mathrm{BDT})\end{array}$ & $\begin{array}{c}\text { Price paid by } \\
\text { consumers (in } \\
\text { BDT) }\end{array}$ & $\begin{array}{l}\text { Price Spread } \\
\quad \text { (in BDT) }\end{array}$ \\
\hline \multicolumn{4}{|l|}{ Mango per ton } \\
\hline Farmer - Faria - Consumer & 35000 & 55000 & 20000 \\
\hline Farmer - Faria - Retailer - Consumer & 35000 & 73000 & 38000 \\
\hline $\begin{array}{l}\text { Farmer - Bepari - Aratdar (Chittagong market) - } \\
\text { Retailer - Consumer }\end{array}$ & 30000 & 73000 & 43000 \\
\hline $\begin{array}{l}\text { Farmer - Bepari - Wholesaler (Feni market) - } \\
\text { Retailer - Consumer }\end{array}$ & 30000 & 62000 & 32000 \\
\hline Farmer - Bepari - Consumer & 30000 & 50000 & 20000 \\
\hline \multicolumn{4}{|l|}{ Jackfruit per 100 pieces } \\
\hline Farmer - Bepari - Consumer & 2000 & 6000 & 4000 \\
\hline $\begin{array}{l}\text { Farmer - Bepari - Aratdar (Chittagong market) - } \\
\text { Consumer (Chittagong) }\end{array}$ & 2000 & 7000 & 5000 \\
\hline Farmer - Faria - Retailer - Consumer & 2000 & 10000 & 8000 \\
\hline Farmer - Faria - Consumer & 2000 & 5300 & 3300 \\
\hline \multicolumn{4}{|l|}{ Litchi per 1000 pieces } \\
\hline Farmer - Faria - Consumer & 2000 & 3500 & 1500 \\
\hline Farmer - Faria - Retailer - Consumer & 2000 & 5000 & 3000 \\
\hline Farmer - Bepari - Consumer & 1500 & 3000 & 1500 \\
\hline $\begin{array}{l}\text { Farmer - Bepari - Aratdar (Chittagong) - Retailer } \\
\text { (Chittagong) - Consumer }\end{array}$ & 1500 & 5000 & 3500 \\
\hline Farmer - Bepari - Aratdar (Chittagong) - Consumer & 1500 & 4000 & 2500 \\
\hline
\end{tabular}

Table 10. Growers share (\%) in marketing channel of fruits (mango, jackfruit, and litchi).

\begin{tabular}{|c|c|c|c|}
\hline Marketing channel & $\begin{array}{l}\text { Price received by } \\
\text { fruit growers (in } \\
\text { BDT) }\end{array}$ & $\begin{array}{c}\text { Price paid by } \\
\text { consumers (in } \\
\text { BDT) }\end{array}$ & $\begin{array}{c}\text { Growers } \\
\text { Share (\%) }\end{array}$ \\
\hline \multicolumn{4}{|l|}{ Mango per ton } \\
\hline Farmer - Faria - Consumer & 35000 & 55000 & 63.64 \\
\hline Farmer - Faria - Retailer - Consumer & 35000 & 73000 & 47.95 \\
\hline $\begin{array}{l}\text { Farmer - Bepari - Aratdar (Chittagong market) - } \\
\text { Retailer - Consumer }\end{array}$ & 30000 & 73000 & 41.09 \\
\hline $\begin{array}{l}\text { Farmer - Bepari - Wholesaler (Feni market) - Retailer - } \\
\text { Consumer }\end{array}$ & 30000 & 62000 & 48.38 \\
\hline Farmer - Bepari - Consumer & 30000 & 50000 & 60 \\
\hline \multicolumn{4}{|l|}{ Jackfruit per 100 pieces } \\
\hline Farmer - Bepari - Consumer & 2000 & 6000 & 33.33 \\
\hline $\begin{array}{l}\text { Farmer - Bepari - Aratdar (Chittagong market) - } \\
\text { Consumer (Chittagong) }\end{array}$ & 2000 & 7000 & 28.57 \\
\hline Farmer - Faria - Retailer - Consumer & 2000 & 10000 & 20 \\
\hline Farmer - Faria - Consumer & 2000 & 5300 & 37.74 \\
\hline \multicolumn{4}{|l|}{ Litchi per 1000 pieces } \\
\hline Farmer - Faria - Consumer & 2000 & 3500 & 57.14 \\
\hline Farmer - Faria - Retailer - Consumer & 2000 & 5000 & 40 \\
\hline Farmer - Bepari - Consumer & 1500 & 3000 & 50 \\
\hline $\begin{array}{l}\text { Farmer - Bepari - Aratdar (Chittagong) - Retailer } \\
\text { (Chittagong) - Consumer }\end{array}$ & 1500 & 5000 & 30 \\
\hline Farmer - Bepari - Aratdar (Chittagong) - Consumer & 1500 & 4000 & 37.5 \\
\hline
\end{tabular}


Table 11. Acharya's marketing efficiency of various channels in fruits (mango, jackfruit, and litchi) marketing.

\begin{tabular}{|c|c|c|c|c|}
\hline Marketing channel & $\begin{array}{l}\text { Price received } \\
\text { by fruit growers } \\
\text { (in BDT) }\end{array}$ & $\begin{array}{c}\text { Total } \\
\text { marketing } \\
\text { cost (in BDT) }\end{array}$ & $\begin{array}{l}\text { Net Marketing } \\
\text { margin (in BDT) }\end{array}$ & $\begin{array}{l}\text { Marketing } \\
\text { Efficiency }\end{array}$ \\
\hline \multicolumn{5}{|l|}{ Mango per ton } \\
\hline Farmer - Faria - Consumer & 35000 & 5229.286 & 16437.48 & 1.62 \\
\hline Farmer - Faria - Retailer - Consumer & 35000 & 9391.167 & 8942.16 & 1.91 \\
\hline $\begin{array}{l}\text { Farmer - Bepari - Aratdar (Chittagong } \\
\text { market) - Retailer - Consumer }\end{array}$ & 30000 & 9291.08 & 4549.98 & 2.17 \\
\hline $\begin{array}{l}\text { Farmer - Bepari - Wholesaler (Feni } \\
\text { market) - Retailer - Consumer }\end{array}$ & 30000 & 12868.87 & 5545.66 & 1.63 \\
\hline Farmer - Bepari - Consumer & 30000 & 18601.2 & 1399 & 1.49 \\
\hline \multicolumn{5}{|l|}{ Jackfruit per 100 pieces } \\
\hline Farmer - Bepari - Consumer & 2000 & 3280.67 & 219.33 & 0.57 \\
\hline $\begin{array}{l}\text { Farmer - Bepari - Aratdar (Chittagong } \\
\text { market) - Consumer (Chittagong) }\end{array}$ & 3500 & 2562.12 & 187.88 & 1.27 \\
\hline Farmer - Faria - Retailer - Consumer & 3650 & 2325 & 1675 & 0.91 \\
\hline Farmer - Faria - Consumer & 2000 & 1417 & 1883 & 0.61 \\
\hline \multicolumn{5}{|l|}{ Litchi per 1000 pieces } \\
\hline Farmer - Faria - Consumer & 2000 & 862.5 & 137.5 & 2.00 \\
\hline Farmer - Faria - Retailer - Consumer & 3650 & 2325 & 1675 & 0.91 \\
\hline Farmer - Bepari - Consumer & 1500 & 1020 & 480 & 1.00 \\
\hline $\begin{array}{l}\text { Farmer - Bepari - Aratdar (Chittagong) } \\
\text { - Retailer (Chittagong) - Consumer }\end{array}$ & 1500 & 1253.57 & 246.43 & 1.00 \\
\hline $\begin{array}{l}\text { Farmer - Bepari - Aratdar (Chittagong) } \\
\text { - Consumer }\end{array}$ & 1500 & 900.68 & 99.32 & 1.50 \\
\hline
\end{tabular}

\section{CONCLUSION}

The majority of the market actors depends mainly on agricultural activities and engage themselves thoroughly in the production and marketing of seasonal fruits. The most common mango variety transported to various markets was the Rangui type, as the displays of other varieties were in short supply. Other fruits, such as jackfruit and litchi, were also more popular at the local market than in the distant market. For mango (Rangui variety), the retailer's net margin or profit was more significant than the other actors. In contrast, the net marketing margin of Faria was higher when they supplied jackfruit in the market. Also, the highest net margin was received by Bepari for litchi trading. The most efficient marketing channel for mango was "farmer-Bepari-Aratdar-retailer-consumer." Whereas for jackfruit, (farmer-Bepari-Aratdar-consumer) was found to have an efficient channel, and for litchi, (farmer-Faria-consumer) had the highest marketing efficiency.

Funding: This study is funded by Bangladesh Krishi Gobeshona Endowment Trust (BKGET) under Krishi Gobeshona Foundation (KGF), Dhaka. The funding number is Commissioned Research Program (CRP-IV). Competing Interests: The authors declare that they have no competing interests.

Authors' Contributions: All authors contributed equally to the conception and design of the study.

\section{REFERENCES}

[1] Daily Asian Age, "Prospects of hill fruits of Chittagong hill tracts. Retrieved from https://dailyasianage.com/news/253912/prospects-of-hill-fruits-of-chittagong-hill-tracts," 2021.

[2] The Daily Star, "CHT fruit growers given short end of the stick. Retrieved from https://www.thedailystar.net/business/news/cht-fruit-growers-given-short-end-the-stick-1895824," 2020.

[3] Department of Agriculture Forestry and Fisheries, Linking producers to markets programme. South Africa: Directorate Marketing: Department of Agriculture, Forestry and Fisheries, 2012.

[4] A. Tadesse, Market chain analysis of fruits for gomma woreda, Jima zone, Oromia national regional state. Haramaya: Haramaya University, 2011. 
[5] K. M. Aujla, M. Abbas, K. Mahmood, and S. Saadullah, "Marketing system of fruits, margins and export potential in Pakistan," Pakistan Journal of Life and Social Sciences, vol. 5, pp. 34-39, 2007.

[6] M. J. Uddin, S. Dey, and T. Taslim, "Trend and output growth analysis of major fruits in Chittagong region of Bangladesh," Bangladesh Journal of Agricultural Research, vol. 41, pp. 137-150, 2016.Available at: https://doi.org/10.3329/bjar.v41i1.27679.

[7] B. Dewan, "Scenario of major fruits production and marketing system in Chittagong hill tracts: Study based on Khagrachari Hill District, Bangladesh," International Journal of Economics, Commerce and Management, vol. 3, pp. 966$977,2015$.

[8] M. J. Islam, "Contextual estimation of marketable and marketed surplus of selected seasonal fruits: A study based on Chittagong Hill tracts (CHT) of Bangladesh," International Journal of Sustainable Agricultural Research, vol. 6, pp. 21-32, 2019.Available at: https://doi.org/10.18488/journal.70.2019.61.21.32.

[9] A. Y. Sampa, M. A. Alam, M. A. Latif, and M. M. Islam, "Socio-economic status and rationale of mango cultivation based on some selected areas in Rajshahi district of Bangladesh," Research in Agriculture Livestock and Fisheries, vol. 6, pp. 79-90, 2019.Available at: https://doi.org/10.3329/ralf.v6i1.41389.

[10] G. Muhanji, R. L. Roothaert, C. Webo, and M. Stanley, "African indigenous vegetable enterprises and market access for small-scale farmers in East Africa," International Journal of Agricultural Sustainability, vol. 9, pp. 194-202, 2011.Available at: https://doi.org/10.3763/ijas.2010.0561.

[11] G. Shepherd, Marketing offarm products. Iowa: Iowa State University Press, USA, 1972.

[12] L. B. Hugar and K. C. Hiremath, "Efficiency of alternative channels in the marketing of vegetables in Belgium City," Indian Journal of Agricultural Economics, vol. 39, pp. 192-200, 1984.

[13] S. S. Acharya and N. Agarwal, Agricultural marketing in India, 4th ed. New Delhi: Oxford IBH Publishing Co. Pvt. Ltd, 2004.

[14] E-Krishi Shiksha, "Horti-business management (2+0)." India: Retrieved from: http://ecoursesonline.iasri.res.in/mod/page/view.php?id=16979. [Accessed October 22, 2021], 2012. 